\title{
Chapter 1 \\ Political Protest in Asylum \\ and Deportation. An Introduction
}

\author{
Sieglinde Rosenberger
}

European societies have been confronted with rapid social and cultural transformation, which took on a new magnitude with the "long summer of migration" in 2015. In general, the perceptions and experiences of change never go uncontested; change gives rise to conflicts and struggles over collective identities, policy, and legal responses. International migration flows and related issues such as asylum and the deportation of non-citizens have grown into one of Europe's most controversial and politicized topics. Political parties campaign on these issues, but there is also political protest articulated by movements, activists, grassroots organizations and ordinary citizens. These acts of resistance are gaining in qualitative and quantitative importance. They include voices for more liberal and open stances towards migration on the one hand, and voices calling for greater deterrents and coercive policy approaches on the other (Daphi 2016; Simsa 2017).

However, although it has recently intensified, this contestation from below is by no means new. As early as the 1980s, migrants, citizens, and advocacy groups were siding with migrants and asylum seekers, promoting inclusion and legal and social rights. The same is true for the right-wing groups acting collectively against immigrants and asylum seekers, marching in cities, attacking accommodation centers, and petitioning for stricter asylum regulations towards newcomers. In short, there is a history of political protest around migration, which has intervened in political processes, challenged representative authorities, and affected public debate and policymaking (Kriesi 2011; Caiani and Borri 2016; Cinalli 2016).

Research on political protest and contestation in areas like migration, asylum, and deportation constitutes a growing academic field. More recently, anti-deportation campaigns as well as migrant struggles and refugee activism have received a great deal of scholarly attention (Tazreiter 2010; Freedman 2011; Rygiel 2011; Tyler and Marciniak 2013; Rosenberger and Winkler 2014; Hasselberg 2014). However, much

\footnotetext{
S. Rosenberger $(\square)$

University of Vienna, Vienna, Austria

e-mail: sieglinde.rosenberger@univie.ac.at
} 
of the academic literature has concentrated on individual country studies and has mostly considered one type of protest (della Porta and Diani 2006). Moreover, as Accornero and Fillieule $(2016,9)$ have highlighted, the main focus is on progressive or left-wing mobilization, which is being examined using the instruments of protest and social movement research. Only recently has scholarship also started to employ these tools to investigate conservative or right-wing mobilization. To date, restrictionist mobilization has predominantly been investigated using lines of thought borrowed from the study of right-wing and populist political parties (Caiani et al. 2012). Hence, broader comparisons which take into account the role of different political environments, different national and local contexts, as well as observations of different types of resistance are considered a research lacuna.

This is the point at which this book steps in. The volume deals with contestation and demands around asylum and deportation through the "unconventional tool" of protest. The main research questions the chapters attempt to answer are how and why protest occurs in these fields, how actors engage with and resist the forceful removal of non-citizens on the one hand, and how actors resist the reception of asylum seekers on the other.

Based on comparative approaches across time, political space, and various types of protests, as well as on in-depth case studies, the individual chapters provide insights into ongoing mobilization and resistance within civil society. They cover struggles for and by, but also against, the rights and needs of asylum seekers. Special attention is given, first, to organizational aspects and constellations of actors within diverse networks and, second, to the interactions between protesters and state actors. In more theoretical terms, the book deals, on the one hand, with the power of civil society and individuals, citizens and non-citizens, as well as with various cycles of policymaking in asylum and deportation; on the other hand, it covers the limitations of a liberal state's coercive capacity to control borders and to make decisions about non-citizens who may stay within its territory. Classical studies of deportation regimes frame resistance against forced removals as a "contentious relationship between sovereignty, space, and the freedom of movement." (Peutz and De Genova 2010, 2).

\subsection{Defining Protest}

In very general terms, political protest is about conflicts and is defined as the "joint (i.e. collective) action of individuals aimed at achieving their goal or goals by influencing decisions of a target." (Opp 2009, 44) The ultimate goal of political protest is to have an impact on decision makers. The objectives of political protest therefore range from raising awareness over the conflict in question to stirring up public debate and controversy to providing the wider public with information on the topic and mobilizing people to engage and join a protest group (Kriesi 2011, 294-295).

Following Opp's classical definition, two constitutive components related to the research presented in this book should be clarified: target (the addressees of protest) and decisions (the substantive focus). 
The main target or opponent of protest in asylum and deportation is the nation state, its institutions and political processes, and the authorities responsible for policy adoption as well as policy implementation. The nation state still has the legal competence to regulate and implement asylum procedures and make decisions on reception, accommodation, and deportation. Although a process of Europeanization of respective asylum regimes has begun, implying a shift of asylum regulation from the national to the European level, the core competence still lies within the responsibility of member states.

At first glance, pro-migrant protesters advance interests that include the right to remain for an individual and their family, and securing a particular status and humane living environment. Anti-migrant protesters, in contrast, object to migrants' right to settle or to the creation of asylum facilities. However, a closer look reveals that fundamental principles regarding the nation state are at stake when protesters make asylum-oriented claims and attempt to influence governmental decisions (Rucht 2002, 4). The issue of asylum and deportation is one of extraordinary statecraft, it is about national sovereignty over borders and territory, about citizenship and membership. In this vein, state authorities claim that the forced removal of noncitizens is a necessary measure to demonstrate the capacity to control migration and is proof of the state's sovereignty over its borders. Protest against deportations can thus be read as an intervention into a state's potential to regulate transnational human mobility. Ultimately, both pro- and anti-asylum protests target policy decisions related to the core interests of the nation state, its sovereignty and its statecraft (Giugni and Yamasaki 2009).

The substantive focus of this collection is asylum and deportation policies. Without any doubt, this is a social and political field with some noteworthy particularities that impact on the ways protest emerges and people engage with the issue. Activists' experiences, their collective actions, concern a field about which many citizens have strong opinions and emotions, both positive and negative. Despite the fact that asylum seekers and recognized refugees have long been largely invisible in the public sphere, the issue of asylum itself is "hypervisible" (Tyler and Marciniak 2013, 152), in other words, it is highly politicized and polarized. A further aspect concerns the characteristics of the affected persons. Obviously, those who are affected by protest are relatively powerless groups who lack most conventional political resources. In particular, they lack the organizational capacity and voting power relevant to stage resistance and to put pressure on decision-makers (Lipsky 1968, 1144). Specifically, asylum seekers and potential deportees are widely deprived of rights, residential security, and social welfare and may be viewed as a vulnerable group. Judith Butler (2009) has criticized the normative social and legal marginalization of refugees (used as a political and not a legal term) as a nonrecognition of the lives of migrants. A recognition of these lives would thus be a protest for the right to remain, for freedom of movement, or for better living conditions. The famous phrase "the right to have rights" (Benhabib 2004, citing Hannah Arendt) poignantly describes one of the main forms of contestation examined in this volume. 
All in all, these briefly cited characteristics inherent to the issue of asylum and deportation are assumed to be relevant to the emergence, form, and consequences of protest activities and state responses to them (Freedman 2011, 618). As this book will demonstrate, these peculiarities are also reflected in the relevance of solidarity, social relations and emotional ties, which influence the composition of protest networks and the way their dynamics shape strategies and outcomes. In this regard, the micro-level of individual behavior meets the macro-level of structures and environments that facilitate or hinder individual acts of engagement (Opp 2009; Kriesi 2011; Duyvendak and Jasper 2015).

We will come back to theoretical approaches in the following sections. Before doing so, we discuss why we favor the term political protest over social movement.

In contrast to various studies on campaigns and protest for the right of asylum seekers that refer to themselves, intentionally or unintentionally, as social movements, we tend to favor the term political protest. Karl-Dieter Opp (2009, 41) reminds us of two criteria: "[t]he larger the protest group is and the more formal its organization is, the closer it comes to a social movement." Although the literature does not provide clear-cut definitions and stable boundaries, in the research presented in this book we could not find sufficient evidence that the collective activities investigated were launched by large groups which could rely on formal internal organizations. Thus, political protest is seen as the more fitting term to grasp and frame what is happening on the ground.

Finally, some remarks on definitions. With regard to terminology, in this edited volume we use the term anti-asylum protest and anti-deportation protest to refer to protest activities staged in the field of asylum (accommodation) and deportation (forceful removal of non-citizens from a territory and from social relations). Regarding different migrant categories addressed in this volume, the anti-deportation protests pertain to rejected asylum seekers (mainly in Austria), but also to irregular migrants and third country nationals with a toleration card. Anti-asylum protest is directed against asylum seekers who have filed a request for protection and are accommodated in collective asylum centers distributed around the country. The geographical spread of this volume is Austria, Germany, and Switzerland. All three are countries of immigration and have well established policy frameworks for asylum and deportation. The three countries differ, however, in national specifics regarding the direct involvement of citizens in policymaking, their protest cultures, and regarding the degree to which each is a "social movement society" (Meyer and Tarrow 1998).

\subsection{Aims of the Volume}

The volume has several aims and strives to bring together relevant empirical, analytical, and theoretical contributions that advance the study of political protest in the policy fields of asylum and deportation. 
To begin with, the essays aim to draw a nuanced picture of political contestation from the bottom up, of political rifts that run through societies, and of tensions and relations between institutional politics and protest groups. They attempt to provide wide-ranging coverage of anti-asylum and anti-deportation protest activities. To this end, we have developed a typology of three manifestations of protest: solidarity protests, refugee activism, and right-wing restrictionist protests. The book also contributes to the understanding of how protest from below affects the politicization of asylum and deportation and policymaking in the field, as well as taking a distinctive look at politicization through political parties and interest groups (see also Caiani and Borri 2016; Rosenberger and Ruedin 2017).

Second, the volume aims to advance the state of the art of key features of political protest. It attempts to produce rigorous knowledge on actors, agency, and interactions by combining theory with empirical research. Two expressions of interaction are central: vertical and horizontal interaction between protest groups, and interaction between protest groups and state actors. Comparing different forms of protest across time and political spaces, the volume offers fine-grained empirical knowledge on configurations of actors and their repertoires, on strategies, and on the consequences of protest. The findings demonstrate how diverse protest networks are and that much depends on their thematic focus: in anti-deportation protests, ordinary citizens along with groups representing civil society and activists dominate the protest networks; in anti-asylum protests, ordinary citizens along with institutional representatives, political parties, and elected officials dominate the scene. Different forms of protest elicit different forms of overlap and interaction between groups of protesters, institutional and non-institutional actors, and experienced activists and non-experienced citizens, who share and deploy their resources and capacities to organize resistance.

Third, a further aim is to shed light on the range of goals expressed within the scope of aspiring to social and political change. Pro- and anti-migrant struggles are often grounded in case-based mobilization at a local level rather than in a desire to change policy (Ellermann 2009). However, the significance of case-based mobilization varies across countries and not only makes a difference in specific cases but also serves as a strategic means to mobilize for policy change. In this regard, the chapters contribute to the study of protest as case-based mobilization at local levels on the one hand, and as seeking change in the understandings and narratives of the rightfulness of migration restrictions on the other.

Fourth, the chapters attempt to expand knowledge of the liberal paradox, a term invented by Hollifield (2008). The term liberal paradox designates the tension between (restrictive) national laws and international regulations that provide basic rights for all human beings. Two diverging concepts of politics, the nation-bound and the cosmopolitan, are at stake here. However, as this volume shows, it is not only states that are confronted with the liberal paradox but also political protest networks. Anti-migrant protest activities stress concepts and ideas such as national sovereignty as well as the sovereignty of the national demos. Pro-migrant protest 
relates to universal understandings of human rights and mobility, citizenship and membership. However, different protest networks address this challenge in different ways.

Fifth, the main concern within protest and social movement research relates to the question of what fosters and enables protest activities. Why do people and organizations get involved? Such questions lead us to theoretical perspectives. The individual chapters here engage with and draw on different traditions of thought, combining micro-level perspectives such as motives, incentives, and social relations with macro-level perspectives such as social structures and political frameworks, integrating endogenous and exogenous factors relevant to protest (for an overview of approaches, see Meyer and Minkoff 2004; della Porta and Diani 2006; Opp 2009; Roose and Dietz 2016). In this book, great attention is paid to an approach we term political opportunity. Yet at the same time, some of the essays collected here underscore the explanatory power of local factors (Daphi 2016). Moreover, chapters on refugee activism refer to the model of resource mobilization, which foregrounds the strategies, networks, and ties between distinct groups and their resources. Following these approaches, we strive to contribute to state of the art scholarship in this field by combining several theoretical and analytical perspectives, enabling us to arrive at a better understanding of the protests targeted at key state interests.

The following section offers an outline of the three aforementioned manifestations of protest, presents some of their features, and provides an outlook on the empirical research findings discussed in the later chapters of the book.

\subsection{Manifestations of Protest in Asylum and Deportation}

In the interest of a broad understanding of political protest, the volume expands the scope of classical social movement scholarship by bringing together progressive, leftist movements with protest originating in right-wing populist and nativist movements. For this purpose, we have developed a typology of three manifestations: solidarity protests, refugee activism, and right-wing restrictionist protests.

This typology is based on two variables: actors (who organize and make demands) and goals (expanding or restricting rights). Although modified here, this typology resembles the classification of protest and social movements provided by sociologist Robert Schaeffer (2014). Applying the lens of social change, Schaeffer distinguished between aspiring, altruistic, and restrictionist movements. Altruistic and aspiring movements function in a transformative way, are aimed at social change and are inclusive. In contrast, restrictionist movements pursue nationalist and xenophobic activities, defend social inequality, oppose processes of democratization or aim at exclusion directed towards non-citizens (ibid., 12).

Below we describe some of the features of these three distinct forms of protest and provide explanations for their emergence. 


\subsubsection{Solidarity Protest Against Deportations}

The literature on protest in asylum and deportation covers diverse initiatives in various countries that support of the social needs and fundamental rights of asylum seekers and irregular migrants. Citizens, grassroots associations, advocacy groups and social movements organize and participate in collective actions, activate their networks, and share their knowledge and influence with marginalized beneficiaries. As numerous studies have demonstrated, solidarity protests have become a collective actor in challenging the machinery of asylum and deportation (Freedman 2009; Tazreiter 2010; Hasselberg 2014).

Drawing on existing literature and research findings from the Taking Sides project $^{1}$, we can identify three main features in solidarity movements. Firstly, the individuals and informal networks which dominate protest groups act in the interests of others. Not oriented towards self-interest, they defend the rights, needs, and interests of those less fortunate or powerful than themselves. This kind of political altruism is aimed at the inclusion of individuals and groups deprived of rights and secure status. Protesters' concerns and goals are considered altruistic, with the outcomes benefitting others (on political altruism see Giugni and Passy 2001).

Secondly, moral principles and an ethical vision rather than material interests or personal privileges motivate people to turn to collective action. Solidarity networks express discontent and grievances about specific policies and seek justice, dignity, and fair treatment. Often protest communications and narratives advance a rationale of values, morality, and arguments about what is just and humane, and about the kind of individuals that create a society (Ellermann 2014; Kusche 2016).

Thirdly, compared to other protest forms, solidarity protests take on very specific contours. In terms of instruments, these are mainly low-level and the types of actors extend beyond classic movement activists. Citizens and grassroots groupings with diverse ideological views and backgrounds organize and participate in these protest activities. In most cases, protest is not staged in line with traditional political divisions but goes beyond the usual basis of collective action and party lines, thus blurring party affiliations and embracing participants from all walks of life (see Part III in this volume).

This brings us to the question of how and why discontent and social grievances over the state of deportability translate into actions of solidarity. Both macro- and micro-level approaches are decisive for understanding why people decide to participate in unconventional political activities. Different opportunity structures foster or hinder access to collective actions (Meyer and Minkoff 2004). Moreover, emotional processes at a subjective level foster protest development, for instance, when people experience moral shocks (Jasper 2014) because migrants they know personally and

\footnotetext{
${ }^{1}$ inex.univie.ac.at/research/taking-sides/
} 
have ties with receive a deportation order. This emotionally strained situation can move citizens to act by putting pressure on state authorities to revoke a decision.

\subsubsection{Refugee Activism for Social Inclusion}

In terms of saliency, collective demands by rejected asylum seekers and irregular migrants for their rights are a rare and recent phenomenon. The obvious reason for this rarity is that irregular migrants lack the capacities for self-representation, the organizational infrastructure, as well as the resources to mobilize for a successful struggle. Their status as non-citizens, including insecure residence titles, makes involvement in protest risky and costly. Collective action, however, requires many more resources and is difficult to organize and launch. Civil disobedience and hunger strikes have often been refugees' only means of raising their voices and resisting deportation (Rygiel 2011, 3; Chimienti 2011; Tyler and Marciniak 2013, 152).

Nevertheless, more recently, migrants with insecure status have been taking action all over Europe, organizing and participating in protests against deportation and for social inclusion and freedom of movement. In these struggles for membership, migrants have become visible political subjects. Consequently, Tyler and Marciniak $(2013,143)$ have concluded that "refugee activism has become a significant political force in its own right."

Academic literature and advocacy organizations alike refer to agency and capture this form of protest with the concept of citizenship from below (Tyler and Marciniak 2013; Ataç et al. 2016). Moreover, when asylum seekers and irregular migrants mobilize to lobby for legal and social rights they speak of self-organized protest. However, others question this emphasis on self-organization to describe refugee activism. Following the resource model approach in social movement studies (Opp 2009), it has become clear that these acts of resistance also require infrastructural resources, which are in fact provided by actors with greater access to resources. Together, protest groups consisting of both citizens and non-citizens organize collective activities and put pressure on state authorities to modify migration policies and/or their enforcement. Refugee activism relies on vertical solidarity networks (della Porta and Diani 2006, 15) or, as Granovetter (1983) calls them, on weak and strong ties between civil society and non-citizens. In this volume, the chapters in Part IV elaborate on vertical networks from different angles.

\subsubsection{Restrictive Protest Against Asylum Seekers}

Scholarly debates disagree on whether right-wing groups that mobilize and run campaigns against migrants and asylum seekers qualify as social movements (see Caiani et al. 2012). Schaeffer's work (2014) not only looked at progressive movements but also at political protest and social movements which seek to preserve 
inequality and prevent others from acquiring similar rights and citizenship. Schaeffer termed these movements restrictionist movements, while della Porta and Diani $(2006,31)$ called them ethno-nationalist movements.

In several European countries, restrictionist protests against the reception of new asylum seekers have been observed for years (for example Grillo 2005). In the wake of the massive influx of migrants from the Global South and from war-torn countries, right-wing initiatives have grown and taken to the streets in larger numbers. They aim to stop decision-makers from accepting asylum seekers and their protests communicate a belief in the sovereignty of the nation state as the legitimate authority for dealing with asylum. Moreover, protesters emphasize the right of their country's nationals to determine who enters a territory and who has the right to stay.

One main feature of restrictionist protest is its network configuration, namely the overlap between institutional and non-institutional actors. Drawing on Goldstone (2003), protest and social movements should not be considered merely as outsiders or challengers to the polity because they do have access to institutionalized politics. This proposition is true for anti-asylum protest, but it clearly goes beyond this. In the cases presented here, several close links between institutional politics and extraparliamentary contestation are evident. For instance, protests against asylum accommodation intersect closely with institutional actors. Often local and/or opposition politicians use the instrument of protest to counter decisions taken by higher-level government obliging them to take in asylum seekers. For Austria and Germany, the chapters by Haselbacher and Rosenberger (Chap. 12), as well as Rucht (Chap. 11) in this volume show that the arguments and demands of right-wing protest groups resonate with sections of the conservative and far-right parties. Moreover, they demonstrate that institutional politics interact strategically with protest groups, bridging the gap between institutional activities and non-institutional ones. In this regard, protest serves as an instrument of party politics.

In terms of interests, looking at the motives concealed in these protest events, restrictive action is both self-interest-based (the material distribution of private and public goods between citizens and non-citizens) as well as ideology-based (maintaining and strengthening an imagined national homogeneity and nativist culture) (see Haselbacher and Rosenberger 2018).

How and why do grievances about decisions on the reception of refugees translate into collective action? Social movement literature distinguishes between stable and dynamic opportunity structures to underpin the emergence of protest (Cinalli 2016, 88). The two chapters in this book addressing societal resistance to the reception of asylum seekers underline the importance of both historically established paths of far-right mobilization and dynamic, short-term contextual developments such as migration flows to explain the rise of protest.

Finally, a remark on the term refugee activism. Studies refer discursively to refugees, used as a political notion of self-designation which obviously does not correspond with the legal meaning. In legal terms, a refugee is someone who has been recognized as a refugee according to the definition of the Geneva Convention and was granted international protection. Chapters 9 and 10 in this volume dealing with refugee struggles or refugee protest use this self-designation of the protesters- 
asylum seekers, rejected asylum seekers, irregular migrants, and other categories speak about their struggle in terms of refugee protest/refugee struggles.

In sum, one contentious issue runs through all three manifestations of protest, namely the tension between universal and case-specific claims raised by protesters. Against this background, this question will be elaborated in the following section. As this topic is most relevant to pro-migrant protest, the discussion will focus only on anti-deportation protest and refugee activism.

\subsection{Policy Change and Implementation Stop}

Do protests challenge the nation state's right to remove non-citizens or do they challenge the policy enforcement in specific cases? Goodman (2004) investigated the Australian citizen movement of solidarity with refugees, concluding that it oscillated between "humanitarian norms and national identity, between borderless cosmopolitanism and reconstituted nationalism" (ibid., 4). The liberal paradox (Hollifield 2008) lies at the heart of this quotation, with reference not only to the liberal state but also to protest movements. Bearing in mind the research results presented in this book, this statement by Goodman (2004)-implying a confrontation between two distinct political directions-is clearly over-generalized and less nuanced. Solidarity protest movements and refugee activism include both radical claims for borderless human mobility and claims that borders be maintained while allowing a few to stay in the country who are perceived as culturally and economically integrated.

For social movement studies, it has become almost self-evident that individuals and networks engaged in political, social and cultural conflicts lobby for social change. The primary goal of progressive protests and social movements is change and transformation (Passy 2001; Rucht 2002; della Porta and Diani 2006); for rightwing groups it is undoing change (Schaeffer 2014). However, the question remains as to what kind and what degree of change is called for. Several chapters presented in this book engage with different understandings and degrees of social and political change and two specifications in particular are presented: firstly, demands either in favor of or to undo social and political change; and secondly, demands for changes either to policymaking or to policy implementation (Ellermann 2009; Patler and Gonzales 2015, 1468).

To begin with, the overall goal of anti-deportation protests is to combat the forceful removal of rejected asylum seekers or irregular migrants. These protests are carried out by a range of different protest groups. Experienced activists and leftleaning groups pursue a wider objective and aim for political change. These players reject the general logic of the exclusion of non-citizens from the territory and community. The other camp, mainly composed of ordinary citizens and acquaintances, lobby against the enforcement of a particular deportation case carried out in a specific way. We term this latter type implementation protest. It is for the most part neither oriented towards policy reform nor does it demand the modification of 
border control regulations nor a modification of asylum and deportation regimes. Rather, it is characterized by activities aimed at saving certain individuals from being deported or at least at making the deportation practices more humane. Policy implementation protests, including "noble activists" (Anderson et al. 2013, 5) are mainly concerned with what is just and what is not just, as applicable in individual cases. As mentioned above, solidarity action is driven by actors' moral judgments. Solidarity protest takes joint action against the implementation of general rules. The logic of excluding certain people is dismissed, exemptions from the rule are required (for a critical debate, see Walters 2010; Hiemstra 2016). It is the discursive rationale of deservingness which builds the justification for a strategic or moral intervention to expand membership rights to a few "deportable" individuals.

On the question of protesters focusing on the individual enforcement of deportation rather than on policy regulation, Ellermann (2009) has provided a rational choice-oriented answer. She distinguished between the stages of policy design and implementation and found that public attention shifts from the benefits of restrictive policies to the high and individualized costs once they are visible at the implementation stage. However, the question remains as to why policy implementation protests emerge at all. A major strand of theoretical and empirical explanation refers to the phenomenon of social ties and emotions, but also to the subjects of protest, namely the people affected. Most interestingly, Flam (2015) has stressed the function of emotions in eliciting public declarations of sympathy for refugees and irregular migrants.

A revealing account of the role of social determinants relating to the subjects affected by deportability was offered by Patler and Gonzales (2015) in a study on anti-deportation case-based mobilization in the United States. Their findings highlighted that groups with a higher level of social acceptance, such as students, were more likely to receive media coverage and eventually be saved from deportation than less accepted social groups, such as low-wage workers. Whether a group attracts an anti-deportation media campaign thus depends, among other factors, on educational status and income.

As we turn to refugee activism calling for social inclusion and membership, the fundamental demand for social and political change clearly has a different goal. Refugee activism is more radical in that it makes demands concerning modifications to the asylum regime, the machinery of deportation and the right to free transnational movement. In their demands, the (moral) right of a nation state to regulate borders and to decide on entry and stay is disputed (see the chapters by Mokre 2018; Odugbesan and Schwiertz 2018). A potential explanation for this comparatively more radical policy is that refugees have almost nothing to lose and therefore do not feel the need to appeal to political actors and institutions.

However, implementation protests are not only acknowledged but are also the subject of critical reflection in the literature. For instance, Rygiel $(2011,2)$ points out that anti-deportation protests can produce "differentiated modalities of mobilities" and hence "differential inclusion" (ibid., 4). Solidarity protests may well cause political authorities to reverse a decision and to prevent a person and their family from being shunned by the social and political community, with the consequence 
that certain people with negative decisions on their asylum applications are allowed to stay. However, others who were not lucky enough to provoke protest have to leave. Freedman $(2011,620)$ criticizes this aspect as an apolitical form of engagement.

\subsection{The Role of National Contexts}

The scope of the comparative studies and studies oriented towards individual cases examined here spans Austria, Germany and Switzerland. These three countries were chosen because they share some history and some political features, but also differ in some institutional aspects relevant to understanding protest politics. What all three countries have in common is a gradually increasing number of asylum applications, an increasing political tendency to adhere to removal rhetoric and practices, and, finally, few legal arrangements for staying for rejected asylum seekers. In sum, the policy field concerning asylum contains very similar components and tendencies (for more on this, see Part II).

All the same, the three countries present institutional and discursive differences. They differ in protest culture and in the constellations of their political actors. Interestingly, Austria and Switzerland, on the one hand, and Switzerland and Germany, on the other, provide similar contexts for (successful) protest and politicization from below. Austria and Switzerland have in common electorally successful anti-migrant parties that protest, campaign and mobilize against migrant and refugee rights (Gruber 2014). In Germany, a strong anti-migrant party has only recently evolved and protest groups have started taking to the streets in several cities. On the other hand, Switzerland and Germany share a well-established protest culture, including relatively high rates of involvement in politics beyond electoral politics, with direct democracy and demonstrative protest repertoires (Hutter and Teune 2012). In Germany and Switzerland, better opportunities and a greater number of access points exist for direct, non-conventional political expression than in Austria, where a rather moderate protest culture from below is in place (Dolezal and Hutter 2007). So far, Austria does not qualify as what Meyer and Tarrow (1998) call a "social movement society," in which protest activities constitute a major factor in shaping politics and society. For Switzerland, several studies discerned, in general, an open institutional context for protest (Hutter and Giugni 2009; Balsiger 2016). Interestingly, protest by immigrants or against the reception of new asylum seekers is almost non-existent in Switzerland; only anti-deportation protest could be detected.

Collective action against the implementation of deportations has taken place in these countries despite a tendency for public opinion to support restrictive asylum legislation, including the right to carry out forceful removals, and despite the often negative bias of public opinion against immigrants and asylum seekers. In social movement literature, societal support is identified as a relevant structural and discursive factor in protest development (Caiani and Borri 2016; Baumgarten and 
Ulrich 2016). Where societal support is for restrictive asylum legislation, this creates a rather unfavorable opportunity structure for solidarity protests and refugee activism. In two countries, Austria and Switzerland, public opinion backs tough and restrictive asylum and deportation rules. This was slightly different in Germany at the time of investigation, that is until 2016. In contrast, particularly in Austria, restrictive protest organizations face favorable opportunities as their goals are mostly in line with the preferences and sentiments of the majority in society. In sum, solidarity protest and refugee activism have to act against the mainstream; restrictive protest goes mainly with the mainstream.

Last but not least, it should be mentioned that the three countries differ slightly as concerns the existence of and obligation towards the Common European Asylum System. For the European member states Austria and Germany, the European regulations apply in full (e.g. Return Directive, Reception Directive). For the non-EU member state Switzerland, Dublin regulations about responsibilities for asylum procedure also apply. Interestingly, our research shows that the European framework has only a minor impact on protest events and activities.

To summarize, nation state representatives are the main targets of protest politics, and national features influence protest forms and their consequences more than European ones. These national particularities and differences in protest characteristics across countries (see Ruedin et al. 2018) lead us to the conclusion that national structures are still influential for the emergence and dynamics of protest.

Social movement researchers agree that the political environment of a policy field sets important parameters for political protest and mobilization. The concept of political opportunity structure (POS) is defined as the dimensions of the political environment that provide incentives for people to undertake collective action. In other words, the POS is about whether protest groups have easy or difficult access to the political process (Tarrow 1994, 85). The concept is widely used within social movement and political protest studies but has also met with criticism for its conceptual and definitional uncertainty. In particular, for anti-asylum and antideportation protests, the POS-approach is revealing as protest activities challenge nation state authorities directly. In contrast, Kriesi $(2011,298)$ stresses that "cultural authorities will have a greater degree of autonomy from the political context." This remark points to different explanatory powers of political and national contexts, depending on the contested issue. For our theme, we can look very closely at national opportunities and unveil their strength when it comes to understanding political protest around a highly sensitive subject to the nation state-asylum and deportation.

According to Meyer and Minkoff (2004), factors exogenous to protest are more relevant for mobilization and the sorts of demands raised than endogenous factors. This proposition is contested by our findings on asylum protest. We come to the conclusion that endogenous aspects are relevant too and should not missed out (on the differentiation between exogenous and endogenous factors, both of which form the context of protest, see Johnston 2011). One of the most relevant endogenous dimensions is protest as a resource for (further) protest. Our research on all three 
expressions of protest underscores the mechanism of protest waves, namely that protests intensify and spread from one site to another. This observation draws on the argument that controversy itself creates further opportunities for controversy (McAdam et al. 2001). Closely related to this is the view that protest diffusion, feedback and learning take place and can, to a certain extent, explain protest development (Tarrow 2013).

Finally, there is a driving force for protest which is described as neither exogenous nor endogenous: protest as a resource for institutional politics. Protests evolve due to structural grievances at an individual/subjective level, facilitated or hindered by national contexts and frameworks. However, besides grievances, fear and anger over structural transformations, unfair distribution or injustice in an individual case, the source of protest can also lie within the political power situation and dynamics within configurations of political actors. Several chapters in this book address this dimension and show that protest is not purely a meaningful response by citizens to humanitarian crises and social transformations. Protest also has a political basis and contains components of political conflict between actors within a parliamentary setting and party politics. Della Porta and Diani $(2006,19)$ consider social movements as part and parcel of the political system. Protest is politics-or, more precisely, protest is a resource for institutional politics (Lipsky 1968; Goldstone 2003). This observation applies to right-wing protest against asylum seekers, where (local) institutional actors join protest activities and turn to protest repertoires (marches, town meetings, etc.) to resist political decisions taken at regional or federal levels.

\subsection{Methods and Data}

First of all, this volume presents original work from the three-year comparative study "Taking Sides: Protest against the Deportation of Asylum Seekers," which examined anti-deportation protest events in Austria, Germany and Switzerland. In the interest of providing a comprehensive picture of political protest, however, the scope of this book has been expanded and complemented by studies on refugee activism in Hamburg, Osnabrück, and Vienna (see Part IV), as well as by research on right-wing mobilization against asylum seekers (see Part V).

Most, but not all, of the chapters refer to a joint methodological approach within the trilateral Taking Sides research project and to a jointly produced data set and defined categories. The main questions and aims of this volume were developed collectively between all the authors in workshops. Although Parts IV and V cover different time frames and different methods were used to gather and analyze data, the research shares conceptual and theoretical frameworks and contributes to the study of asylum protest.

The chapters use both qualitative and quantitative methods to collect and analyze data. The book is based on one longitudinal study (1993-2013) and several in-depth case studies, either single, multiple or comparative. This mixed method allows for 
both in-depth knowledge and comparisons between different instances of protest mobilization by different constellations of actors across countries and timeframes.

The longitudinal study collected, analyzed, and compared anti-deportation protest events in Austria, Germany and Switzerland over a period of 20 years. For this quantitative study, we applied the method of protest event analysis of media reports about deportations (Koopmans and Rucht 2002; for more on this, see the chapter by Ruedin et al. 2018). Although newspapers do not chronicle all protests that take place, they do provide an important indicator of the public visibility of protest and the intensity of contestation. While a bias exists in terms of the ways in which protest is reported in the news, we argue that because of their publicity, protests presented in mass media are particularly relevant for the general public and policy-makers alike (see Van der Brug et al. 2015 for a similar view) and represent an important incentive for those interested as well as institutional actors to become involved in protest.

Several chapters are based on in-depth case studies of hotly debated instances of local protest. In total, 15 in-depth case studies on the issue of anti-deportation were carried out within the Taking Sides research project. These case studies include interviews with protest actors and politicians, media reports, diverse protest material (leaflets, etc.) and official documents such as newsletters produced by municipalities, etc. The chapters relying on this methodology strive for new insights into protest dynamics, protest success, and protest outcomes. The inquiry refers to forms of cooperation between a broad range of participants (vertical and horizontal networks) and the interaction between protesters and state actors.

The chapters on refugee activism are situated outside the Taking Sides project. They are based on the analysis of a wide range of text material on the protest cases. Moreover, they apply the observation method and focus on the conditions, barriers and support this kind of activism encounters. Chapters 9 and 10 have the additional challenge that the authors were involved in protest activities themselves. This situation offers additional insights on the one hand, but also requires certain skills to maintain distance to the subject of inquiry on the other.

The chapters on right-wing groups focus on the protest activities of recent years and rely on the analysis of several kinds of text material and of protest events reported in media outlets. The codebook used is similar to the one developed for the Taking Sides project.

\subsection{Organization of the Volume}

This book brings together a group of established academics and young scholars in protest research to elaborate on protest trajectories, interactions between different types of actors and state authorities, and mechanisms of (successful) protest for and against refugees. The collected essays are based on both single case studies and comparative findings across time, space and manifestation types. The structure of the 
book reflects the typology of protest manifestations and is grouped into four parts: the three protest types plus a section on political context and issue-specific information.

Part II outlines concrete contextual environments, policy field specifics and information on the target of protest (governments, administrative bodies). To do so, a chapter focusing on each country sets out the stable and dynamic national contexts, including the institutional framework of each country, the functional and territorial distribution of powers, and the party system and form of government. Furthermore, the chapters address issue-specific regulations, such as asylum laws and procedures, deportation laws, and reception and dispersal policies. This is completed by key information on short-term contextual factors, such as the development of asylum applications and numbers of removals. All in all, this forms the national contexts, which, according to the POS-approach, have the power to influence the rise and dynamics of protest as well as to explain differences in forms of protest, actor configurations, and impact. The subsequent chapters in Parts III, IV and V will draw on the contextual framework presented in Chaps. 1, 2, and 3.

Part III concentrates on solidarity protests directed against the deportation of failed asylum seekers (based on the Taking Sides data set and methodology). It includes essays presenting longitudinal perspectives on protest characteristics as well as in-depth knowledge on single protest cases.

In Chap. 5, Didier Ruedin, Sieglinde Rosenberger and Nina Merhaut identify country-specific characteristics of protest events in a longitudinal study covering a time span of 21 years. The analysis shows that the form of anti-deportation protest varies across countries and across time. For instance, most anti-deportation protests target policy implementation in individual cases rather than a change in policy or in policy-making. However, the overall direction depends on the kind of protest networks in question. Protests pursuing transnational goals and criticizing the border regime are more frequent in Germany, as compared with Austria and Switzerland. In Austria, resistance to individual deportations is dominant. The results of this investigation underline country-specific differences in the form taken by protests and explain these findings with reference to national particularities in protest cultures and institutional frameworks for extra-institutional political participation such as direct democracy.

Maren Kirchhoff, Johanna Probst, Helen Schwenken and Verena Stern deal with protest success. They analyze multiple case studies conducted in the three countries of investigation and attempt to detect patterns of successful outcomes (Chap. 6). By addressing the stated deficit of comparisons across country contexts, this chapter uses context factors and sheds light on immediate protest outcomes at an administrative level. Referring to Kolb (2007), they identify a set of institutional mechanisms which have an impact on the prevention of a single deportation. The authors conclude that both specific mechanisms and general opportunity structures facilitate success in anti-deportation protest.

In Chap. 7, Dina Bader and Johanna Probst investigate how and why citizens in Switzerland side with rejected asylum seekers and stand together to protest against the authorities' deportation decisions. According to Bader and Probst, two ideal types of protest can be identified in this field: personifying and exemplifying 
protests. The former involves Swiss citizens with different political orientations coming together with the sole aim of preventing the deportation of a specific person or family who is seen as well integrated and thus deserving of the right to stay. Exemplifying protests are implemented by groups of left-oriented activists, who make strategic use of the case(s) of one or several migrants as examples to illustrate the outcomes of a policy they perceive as unjust and whose reform they demand. Ultimately, the authors draw on endogenous factors to discuss the type of the protest-leftist protest groups stage exemplifying protests, while protesters from different ideological backgrounds, encompassing left and right, experienced and non-experienced citizens, initiate personifying protests.

In Part IV, the chapters focus on recent migrant activism and the solidarity networks linked to this. These chapters are based on in-depth case studies and analyze the nature of protests and the contexts in which asylum seekers and irregular migrants, who are socially marginalized and lack the structural resources needed for resistance, raise their voices, organize, and participate in protest actions. The spotlight is on the conditions which influence their capacity to organize and build alliances to campaign for a right to stay and for better treatment of asylum seekers whose applications are being processed. As mentioned above, the tension between raising universal claims for all those affected or making individual claims to bring about change in single cases also runs through the refugee activism presented here.

Sophie Hinger, Maren Kirchhoff and Ricarda Wiese argue in Chap. 8 that taking into account the concept of deportability helps to gain better knowledge of the dynamics of anti-deportation protests. Based on qualitative fieldwork on the antideportation protests in the city of Osnabrück, where the Alliance against Deportations prevented 36 Dublin transfers from Germany to other European Member States, the authors examine how collective protest undermines the isolating logic of deportability in the moment of an (attempted) deportation. Building social relations and ties becomes a constitutive aspect of anti-deportation mobilization. Moreover, the chapter elaborates on the composition and shared tasks of the protest groups, which include a wide range of participants with and without secure residence status.

In Chap. 9, Abimbola Odugbesan and Helge Schwiertz examine self-organized refugee struggles in Germany. A major element in self-organization is that protesters organize resistance and articulate demands on their own. The authors view these struggles as a "new era of protest," which must be understood as part of a complex history of migratory struggles for membership and social inclusion. The authors argue that specific social and political positions, partly shaped by the so-called German-European migration regime and its hierarchy of legal statuses, provoke conflicts and rifts within the broader movement of migratory and refugee struggles. According to the positions of the actors examined here, the framing of these initiatives often oscillates between general claims for the rights of all migrants and particular claims for the rights of the specific protesting group.

In Chap. 10, Monika Mokre analyzes the Refugee Protest Camp Vienna and inquires into whether a specific structure of political opportunity facilitated the start of the movement. Having traced the history of the camp, the author concludes that it did not have a specific triggering point; rather it can be understood as a contingent 
event. Mokre shows how the protest movement made its interests public by raising universal claims, group claims and individual claims at the same time. Furthermore, she identifies relations between refugees and supporters that reflect the lines of mobilization, strong and weak ties (Granovetter 1983), and a mixture of individual support and collective political action. Most importantly, the protesting asylum seekers established close social relations (friendships) with people of various social backgrounds, citizens and non-citizens, a fact which became an extremely relevant resource for the life of the protest.

Part $\mathrm{V}$ contemplates the scope of progressive protests by examining restrictive protests against the arrival and reception of asylum seekers in Austria and Germany. Interestingly, this kind of restrictive protest is not widespread in Switzerland, which is why we decided against a case study on it. In particular, the Austrian paper indicates a proximity and connection and connectedness between protesters and institutionalized politics, a feature that clearly distinguishes solidarity from restrictive protest movements.

In Chap. 11, Dieter Rucht analyzes protests by right-wing groups against asylum seekers in Germany. The author embeds his analysis in the historical context of increasingly aggressive right-wing populism and right-wing radicalism. Organizationally fragmented but ideologically consistent, as the author stresses, for years this right-wing movement has been driving xenophobic activities forward. Analytically, Rucht demonstrates and proves that the concepts and tools of social movement research can be especially useful in analyzing and explaining the recent upsurge in xenophobic sentiment and activities because they allow insights into internal networks and repertoires that are taken partly from the parliamentarian and partly from the extra-parliamentarian arena.

Miriam Haselbacher and Sieglinde Rosenberger investigate restrictionist protest in Austria in Chap. 12. Examining protest events reported in diverse media channels, the authors elaborate on the features and success of restrictionist protest activities against the establishment of reception centers for (new) asylum seekers. The research findings demonstrate that this protest is mainly local and small-scale, is often initiated and supported by state actors, and is successful in terms of achieving its main demands, namely that the location in question not become operational. The protagonists employ demonstrational as well as confrontational action repertoires. The chapter shows that institutional and discursive opportunities are relevant for the spread of protest activities, whereas their high rate of success is due to the close relationship between protesters and representatives of political parties and political authorities (mayors). Initiating and joining protests is revealed to be a resource used in institutional politics by governing actors to mobilize people and to send signals about their responsiveness towards their constituents.

In Chap. 13, Gianni D'Amato and Helen Schwenken present and discuss the key findings of this volume. Summing up the similarities and differences in the characteristics presented by different forms of protest, this chapter stresses protest diffusion and presents evidence for it. Moreover, four anti-deportation protest impacts are identified: case-specific impacts, as many deportations could be stopped; movement-related impacts in terms of a broadening of protest activities; discursive 
impacts, which lead to public awareness about deportations; and finally, politicizing impacts on the side of protest participants. As the comparative findings in terms of concrete outcomes show, refugee activism tends to be less successful than solidarity protest, and restrictionist protest tends to be more successful in terms of its impact on public debate, framings and policy decisions than solidarity protests. This concluding chapter refers back to some of the features presented in this introduction, but summarizes them more accurately with regard to the empirical evidence and analytical and theoretical approaches.

Finally, on a practical note, the essays compiled in this volume are available via open access. Although there are cross-references between the chapters, our aim was that each text should stand alone. To facilitate this, each follows a similar format: starting with an abstract and key words, providing information on the data and methods used, and ending with a full list of references. This design allows for readers to access each contribution individually.

Nevertheless, we invite you to read the book from cover to cover since we were particularly invested in giving it an overall arc and we hope that the entire volume will be met with interest. Our goal was to present a comprehensive body of work that reflects various levels of protest in the field of asylum and deportation. These protests were therefore compared on national and cross-national levels, quantitatively and qualitatively, and over a period of two decades, as well as more recently and in greater depth. Finally, by moving solidarity protests, refugee activism and restrictionist actions into focus, we shed light on different protest types, thereby complementing a broader picture of protests on behalf of, by and against asylum seekers.

Acknowledgements This volume would not have been possible without the generous funding, over 3 years (2013-2016), provided by the Austrian Science Fund research project Taking Sides (grant agreement number I 1294), the German Research Foundation (grant agreement number SCHW1389/5-I), and the Swiss National Science Foundation (grant agreement number 147359). We are deeply grateful for this support.

The Taking Sides project was coordinated by the University of Vienna/Austria (PI Sieglinde Rosenberger) and was jointly carried out by the University of Neuchâtel/Switzerland (PI Gianni D'Amato) and the University of Osnabrück/Germany (PI Helen Schwenken). We owe debts of gratitude to the PIs for guiding the research project and to the respective research teams for their empirical work, thorough analysis, and for writing reports and chapters. At the University in Vienna, we thank research team members Nina Merhaut, Sarah Meyer, Sarah Nimführ, and Verena Stern; at the University of Neuchâtel thanks go to research team members Dina Bader, Johanna Probst, and Didier Ruedin; and at the University of Osnabrïck thanks go to Maren Kirchhoff and David Lorenz.

We owe debts of gratitude to Miriam Haselbacher, Sophie Hinger, Monika Mokre, Abimbola Odugbesan, Dieter Rucht, Helge Schwiertz, and Ricarda Wiese for their participation in research workshops to develop and fine-tune their research questions and designs. We thank them for their valuable contributions. In particular, we thank Dieter Rucht for valuable comments on early draft versions of several chapters.

Moreover, many thanks go to IMISCOE, the European network of scholars in the area of migration and integration, for financial support of the publication at hand. We would also like to thank their excellent staff, most notably Warda Belabas, as well as the Springer Press for the 
productive collaboration. Additionally, we are grateful to the three anonymous reviewers for their helpful feedback on the entire draft manuscript, which strengthened the book tremendously.

Finally, we thank Sandra Müller, Tim Corbett, Matt Rees, and Joanna White for their competent assistance in preparing the manuscript and their language editing respectively.

\section{References}

Accornero, G., \& Fillieule, O. (2016). Introduction. 'So many as the stars of the sky in multitude, and as the sand which is by the sea shore innumerable': European social movement research in perspective. In O. Fillieule \& G. Accornero (Eds.), Social movement studies in Europe. The state of the art (pp. 1-18). New York/Oxford: Berghahn.

Anderson, B., Gibney, M., \& Paoletti, E. (2013). Introduction. In B. Anderson, M. Gibney, \& E. Paoletti (Eds.), The social, political and historical contours of deportation (pp. 1-7). New York: Springer.

Ataç, I., Rygiel, K., \& Stierl, M. (2016). Introduction: The contentious politics of refugee and migrant protests and solidarity movements: Remaking citizenship from the margins. Citizenship Studies, 20(5), 527-544.

Balsiger, P. (2016). The land of opportunities? Social movement studies in Switzerland. In O. Fillieule \& G. Accornero (Eds.), Social movement studies in Europe. The state of the art (pp. 288-302). New York/Oxford: Berghahn.

Baumgarten, B., \& Ulrich, P. (2016). Discourse, power, and governmentality. Social movement research with and beyond Foucault. In J. Roose \& H. Dietz (Eds.), Social theory and social movements. Mutual inspirations (pp. 13-38). Wiesbaden: Springer.

Benhabib, S. (2004). The rights of others. Aliens, residents and citizens. Cambridge: Cambridge University Press.

Butler, J. (2009). Frames of war. When is life grievable? London/New York: Verso.

Caiani, M., \& Borri, R. (2016). Beyond party politics. The search for a unified approach. Research on radical right-wing movements in Europe. In O. Fillieule \& G. Accornero (Eds.), Social movement studies in Europe. The state of the art (pp. 69-85). New York/Oxford: Berghahn.

Caiani, M., della Porta, D., \& Wagemann, C. (Eds.). (2012). Mobilizing on the extreme right. Germany, Italy, and the United States. Oxford: Oxford University Press.

Chimienti, M. (2011). Mobilization of irregular migrants in Europe: A comparative analysis. Ethnic and Racial Studies, 34(8), 1338-1356.

Cinalli, M. (2016). Fields of contentious politics: Migration and ethnic relations. In O. Fillieule \& G. Accornero (Eds.), Social movement studies in Europe. The state of the art (pp. 86-101). New York/Oxford: Berghahn.

Daphi, P. (2016). Reaktionen auf Asylsuchende: Grenzen der Erklärungskraft von Wohlstand und Gruppengröße. Forschungsjournal Soziale Bewegungen, 28(2), 79-83.

Della Porta, D., \& Diani, M. (2006). Social movements. An introduction. Oxford: Blackwell.

Dolezal, M., \& Hutter, S. (2007). Konsensdemokratie unter Druck? Politischer Protest in Österreich, 1975-2005. Österreichische Zeitschrift für Politikwissenschaft, 36(3), 337-352.

Duyvendak, J. W., \& Jasper, J. M. (2015). Breaking down the state. Protesters engaged. Amsterdam: Amsterdam University Press.

Ellermann, A. (2009). States against migrants. Deportation in Germany and the United States. Cambridge: Cambridge University Press.

Ellermann, A. (2014). The rule of law and the right to stay: The moral claims of undocumented migrants. Politics \& Society, 42(3), 293-308.

Flam, H. (2015). Micromobilization and emotions. In D. della Porta \& M. Diani (Eds.), The Oxford handbook of social movements. Oxford: Oxford University Press. 
Freedman, J. (2009). Mobilising against detention and deportation: Collective actions against the detention and deportation of 'failed' asylum seekers in France. French Politics, 7(3-4), 342-359.

Freedman, J. (2011). The Réseau education sans frontières: Reframing the campaign against the deportation of migrants. Citizenship Studies, 15(5), 613-626. https://doi.org/10.1080/136210 25.2011.583793.

Giugni, M., \& Passy, F. (Eds.). (2001). Political altruism? Solidarity movements in international perspective. Lanham: Rowman \& Littlefield.

Giugni, M., \& Yamasaki, S. (2009). The policy impact of social movements: A replication through qualitative comparative analysis. Mobilization, 14(4), 467-484.

Goldstone, J. A. (2003). Introduction: Bridging institutionalized and noninstitutionalized politics. In J. A. Goldstone (Ed.), States, parties and social movements (pp. 1-24). Cambridge: Cambridge University Press.

Goodman, J. (2004, July 7-11). Social movements and refugee solidarity: Breaking the borders or remaking 'the nation'? Paper presented at the 36th World Congress of the International Institute of Sociology. Bejing.

Granovetter, M. (1983). The strength of weak ties: A network theory revisited. Sociological Theory, 1, 201-233.

Grillo, R. (2005). 'Saltdean can't cope'. Protests against asylum seekers in an English seaside suburb. Ethnic and Racial Studies, 28(2), 235-260. https://doi.org/10.1080/0141987042000 0315834.

Gruber, O. (2014). Campaigning in radical right heartland. The politicization of immigration and ethnic relations in Austrian general elections. 1971-2013. Wien: Lit Verlag.

Haselbacher, M., \& Rosenberger, S. (2018). Protest against the reception of asylum seekers in Austria. In S. Rosenberger, V. Stern, \& N. Merhaut (Eds.), Protest movements in asylum and deportation (pp. 247-269). New York: Springer.

Hasselberg, I. (2014). Balancing legitimacy, exceptionality and accountability: On foreign-national offenders' reluctance to engage in anti-deportation campaigns in the UK. Journal of Ethnic and Migration Studies, 41(4), 563-579. https://doi.org/10.1080/1369183X.2014.957173.

Hiemstra, N. (2016). Deportation and detention: Interdisciplinary perspectives, multi-scalar approaches, and new methodological tools. Migration Studies, 4(3), 433-446. https://doi. org/10.1093/migration/mnw017.

Hollifield, J. F. (2008). The liberal paradox: Immigrants, markets and rights in the United States. SMU Law Review, 61(1), 67-91.

Hutter, S., \& Giugni, M. (2009). Protest politics in a changing political context: Switzerland, 1975-2005. Swiss Political Science Review, 15(3), 427-461.

Hutter, S., \& Teune, S. (2012). Deutschlands Protestprofil im Wandel. Aus Politik und Zeitgeschichte, 62(25-26), 9-17.

Jasper, J. (2014). Protest. A cultural introduction to social movements. Cambridge: Polity.

Johnston, H. (2011). States and social movements. New York: Wiley.

Kolb, F. (2007). Protest and opportunities. The political outcomes of social movements. Frankfurt/ Main: Campus.

Koopmans, R., \& Rucht, D. (2002). Protest event analysis. In B. Klandermans \& S. Staggenborg (Eds.), Methods of social movement research (pp. 231-259). Minneapolis: University of Minnesota Press.

Kriesi, H. (2011). Social movements. In D. Caramani (Ed.), Comparative politics (pp. 292-310). Oxford: Oxford University Press.

Kusche, I. (2016). Social movements and sociological systems theory. In J. Roose \& H. Dietz (Eds.), Social theory and social movements. Mutual inspirations (pp. 75-92). Wiesbaden: VS Springer.

Lipsky, M. (1968). Protest as a political resource. American Political Science Review, 62(4), $1144-1158$. 
McAdam, D., Tarrow, S., \& Tilly, C. (2001). Dynamics of contention. Cambridge: Cambridge University Press.

Meyer, D. S., \& Minkoff, D. C. (2004). Conceptualizing political opportunity. Social Forces, 82(4), 1457-1492.

Meyer, D. S., \& Tarrow, S. (1998). The social movement society. Contentious politics for a new century. Lanham: Rowman \& Littlefield.

Mokre, M. (2018). "We demand our rights!" the refugee protest camp Vienna. In S. Rosenberger, V. Stern, \& N. Merhaut (Eds.), Protest movements in asylum and deportation (pp. 205-245). New York: Springer.

Odugbesan, A., \& Schwiertz, H. (2018). "We are here to stay" - refugee struggles in Germany between Unity and Division. In S. Rosenberger, V. Stern, \& N. Merhaut (Eds.), Protest movements in asylum and deportation (pp. 185-203). New York: Springer.

Opp, K.-D. (2009). Theories of political protest and social movements. A multidiscicplinary introduction, critique, and synthesis. London/New York: Routledge.

Passy, F. (2001). Political altruism and the solidarity movement: An introduction. In M. Giugni \& F. Passy (Eds.), Political altruism? Solidarity movements in international perspective (pp. 3-26). Lanham: Rowman \& Littlefield.

Patler, C., \& Gonzales, R. G. (2015). Framing citizenship: Media coverage of anti-deportation cases led by undocumented immigrant youth organizations. Journal of Ethnic and Migration Studies, 41(9), 1453-1474.

Peutz, N., \& De Genova, N. (2010). Introduction. In N. de Genova \& N. Peutz (Eds.), The deportation regime: Sovereignty, space, and the freedom of movement (pp. 1-32). Durham: Duke University Press.

Roose, J., \& Dietz, H. (2016). Social theory and social movements. Mutual inspirations. Wiesbaden: Springer.

Rosenberger, S., \& Ruedin, D. (2017). The politicization of asylum seekers and other immigrant groups in a comparative perspective. In F. Merli \& M. Pöschl (Eds.), Das Asylrecht als Experimentierfeld (pp. 13-26). Wien: MANZ'sche Verlags-und Universitätsbuchhandlung.

Rosenberger, S., \& Winkler, J. (2014). Com/passionate protests: Fighting the deportation of asylum seekers. Mobilization, 19(2), 165-184.

Rucht, D. (2002). Anstösse für den Wandel - Soziale Bewegungen im 21. Jahrhundert. Paper presented at the Gründungsversammlung "Die Bewegungsstiftung - Anstöße für soziale Bewegungen". Berlin: Haus der Demokratie.

Ruedin, D., Rosenberger, S., \& Merhaut, N. (2018). Tracing anti-deportation protests: A longitudinal comparison of Austria, Germany and Switzerland. In S. Rosenberger, V. Stern, \& N. Merhaut (Eds.), Protest movements in asylum and deportation (pp. 89-115). New York: Springer.

Rygiel, K. (2011). Bordering solidarities: Migrant activism and the politics of movement and camps at Calais. Citizenship Studies, 15(1), 1-19.

Schaeffer, R. K. (2014). Social movements and global social change. The rising tide. Lanham: Rowman \& Littlefield.

Simsa, R. (2017). Leaving emergency management in the refugee crisis to civil society? The case of Austria. Journal of Applied Security Research, 12(1), 78-95.

Tarrow, S. (1994). Power in movement. Social movements, collective action and politics. Cambridge: Cambridge University Press.

Tarrow, S. (2013). The language of contention: Revolutions in words, 1688-2012. Cambridge: Cambridge University Press.

Tazreiter, C. (2010). Local to global activism: The movement to protect the right of refugees and asylum seekers. Social Movement Studies, 9(2), 201-214.

Tyler, I., \& Marciniak, K. (2013). Immigrant protest: An introduction. Citizenship Studies, 17(2), 143-156. https://doi.org/10.1080/13621025.2013.780728.

Van der Brug, W., D’Amato, G., Berkhout, J., \& Ruedin, D. (Eds.). (2015). The politicisation of migration. London/New York: Routledge. 
Walters, W. (2010). Deportation, expulsion, and the international police of aliens. In N. Peutz \& N. De Genova (Eds.), The deportation regime. Sovereignty, space, and the freedom of movement (pp. 69-100). Durham: Duke University Press.

Open Access This chapter is licensed under the terms of the Creative Commons Attribution 4.0 International License (http://creativecommons.org/licenses/by/4.0/), which permits use, sharing, adaptation, distribution and reproduction in any medium or format, as long as you give appropriate credit to the original author(s) and the source, provide a link to the Creative Commons license and indicate if changes were made.

The images or other third party material in this chapter are included in the chapter's Creative Commons license, unless indicated otherwise in a credit line to the material. If material is not included in the chapter's Creative Commons license and your intended use is not permitted by statutory regulation or exceeds the permitted use, you will need to obtain permission directly from the copyright holder.

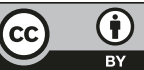

